\title{
Áhrif fiskveiðistjórnunar á virðiskeðju íslensks bolfisks
}

\author{
Ögmundur Knútsson, Háskólinn á Akureyri, ogmundur@unak.is \\ Daði Már Kristófersson, Háskóli Íslands dmk@hi.is \\ Helgi Gestsson, Háskólinn á Akureyri, helgig@unak.is
}

\begin{abstract}
ÁGRIP
Íslenskur sjávarútvegur hefur nokkra sérstöðu samanborið við sjávarútveg nágrannapjóðanna hvað varðar arðsemi. Margir hafa bent á að fyrirkomulag fiskveiðistjórnunar hefur áhrif á rekstrarhegðun útgerðarfyrirtækja og par með afkomu peirra. Afar mikilvægt er, pegar hugað er að breytingum á fiskveiðistjórnunarkerfinu, að fyrir liggi hvað pað er sem leitt hefur til góðrar afkomu í íslenskum sjávarútvegi. Mikilvægt er að breytingar á kerfinu tryggi áframhald pessarrar miklu verðmætasköpunar.

Fyrri rannsóknir höfunda hafa bent til pess að peir prír ytri pættir sem hafa haft hvað mest áhrif á árangur virðiskeðjunnar hérlendis séu afnám útflutningshindrana, fiskveiðistjórnunarkerfið og stofnun fiskmarkaða á Íslandi. Niðurstöður rannsókna benda til pessa að fiskveiðistjórnarkerfið auki skilvirkni virðiskeðjunnar með pví að draga úr sóknarkostnaði, auka sérhæfingu í veiðum, skapi hvata til að auka verðmæti afla og tryggi stöðugleika framboðs hráefnis.

Í pessari grein verða áhrif fiskveiðistjórnunarkerfisins á rekstur sjávarútvegsfyrirtækja könnuð með tvennum hætti. Annars vegar er með djúpviðtölum við stjórnendur í sjávarútvegi könnuð sýn greinarinnar á pátt fiskveiðistjórnunarkerfisins á próun virðiskeðju sjávarútvegs. Hins vegar eru gögn um afkomu greind og borin saman við sambærileg gögn frá Noregi í peim tilgangi að meta hvers vegna próun hér varð önnur en par og draga fram hugsanlegar ástæður pess.
\end{abstract}

\section{ABSTRACT}

In regards to profitability the Icelandic fishing industry stands out among the fishing industries of its neighboring countries. It has often been pointed out that the design of the fisheries management system affects the operational behavior of fishing companies, and thus their earnings. When changes in the fisheries management system are considered it's of vast importance that an extensive knowledge of the system's enablers of profitability has been acquired. Importantly, changes made to the system will still have to enable the industry to maintain such a high profitability.

Former research by the authors has indicated that the three external factors that have significantly affected the effectiveness of the Icelandic fishing industry's value chain are the abolishment of export barriers, the fisheries management system and the establishment of fish markets in Iceland. Research also indicates that the fisheries management system increases the efficiency of the industry's value chain, leads to a decrease in the cost of 
catching, to the intensification in the specialization of fishing and can ensure a steady supply of raw material.

In this paper two different methods are used for analyzing the effects of the Icelandic fisheries management system on the operations of the fishing companies. Firstly, by applying semi- structured interviews the views of Icelandic managers are used to describe the industry's opinion of the management system's influence on the development of its value chain. Secondly, in order to find out why the development of the Icelandic fishing industry differs from that of the Norwegian one and point out possible reasons for that, a comparative analysis of data on profitability from both the Icelandic and the Norwegian fishing industry is used.

\section{JEL- Röðun L1, L2, M210, Q22}

\section{Inngangur}

Fræðileg líkön (Homans og Wilen, 2005) og reynsla af aflamarkskerfum víða um heiminn (Herrmann, 1996, 2000; Larkin og Sylvia, 1999) styðja samhengi arðs af fiskveiðum og aflamarksstýringar veiða. Aflamark breytir aðstöðu fyrirtækja til að stýra framboði á fiski og hafa áhrif á eiginleika hans. Eiginleikar fisks, hvort sem um gæði hans og ferskleika er að ræða, stærð eða afhendingartíma, eru ráðandi um verðmæti hans í augum neytenda (McConnell og Strand, 2000; Daði Már Kristófersson og Kyrre Rickertsen, 2004, 2007). Án öruggs aflamarks leggja útgerðir meiri áherslu á magn fremur en gæði (Homans og Wilen, 2005). Um leið og útgerðin getur gengið að ákveðnu aflamarki vísu breytast áherslurnar og sterkasti hvatinn verður að hámarka arðsemina að gefnu aflamarkinu, sem jafnframt felur í sér að nýta til fullnustu vilja neytenda til að greiða hærra verð fyrir aukin gæði. Petta hefur ekki í för með sér að allur afli verði af bestu mögulegu gæðum, pví gæðum fylgir kostnaður. Petta pýðir einungis að útgerðirnar kappkosta að framleiða pá vöru sem mesta arðinn skapar. Afleiðingarnar eru að skipulag veiða og vinnslu endurspeglar parfir markaðarins um skilvirka miðlun upplýsinga um eiginleika, hvort heldur pað er gegnum markaði eða með lóðréttri sampættingu veiða og vinnslu (Matulich, Mittelhammer og Reberte, 1996; Weninger, 1999; Dawson, 2003).

Раð getur verið erfitt að skilja að áhrif fiskveiðistjórnunarkerfisins og markaðsfyrirkomulags á arðsemi greinarinnar enda eru áhrif peirra samtvinnuð. Reyna má að horfa til nágrannalanda par sem fyrirkomulag hefur verið með öðrum hætti og reyna að meta pannig áhrif hvors um sig. Helst kemur pá til greina að skoða norskan sjávarútveg. Fiskveiðistjórnun á Íslandi og Noregi er að miklu leyti svipuð. Bæði löndin eru með kvótastýrðar fiskveiðar með framseljanlegar aflaheimildir. Í Noregi eru ekki starfandi sambærilegir grunnmarkaðir fyrir afla eins og á Íslandi. Á Íslandi er fullt frelsi með umsetningu afla. Hann er seldur jöfnum höndum gegnum fiskmarkaði til ótengdra aðila, með samningum til fastra samstarfsaðila eða innan sama fyrirtækis til eigin vinnslu. Í Noregi fer mestallur afli gegnum lögboðna söluaðila (n. salgslagene) sem tryggja sjómönnum lágmarksverð samkvæmt lögum sem sett voru 1938 og endurbætt 1951 (n. råfiskloven). Samkvæmt lögunum er refsivert að selja sjávarútvegsafurðir unnar úr hráefni sem ekki hefur verið keypt af pessum söluaðilum. Jafnframt hvílir kaupskylda á kaupanda að öllum afla sem landað er úr ákveðinni veiðiferð. Vegna vissu um trygg kaup á öllum lönduðum afla á 
tilteknu lágmarksverði breytist hámörkunarvandi útgerða í kostnaðarlágmörkun, með fyrrnefndum afleiðingum fyrir eiginleika aflans. Ef útgerð er tryggt lágmarksverð fyrir allan landaðan afla veikist hvatinn til að tryggja gæði vörunnar. Jafnframt verður erfitt fyrir vinnslu að miðla til útgerðar vísbendingum um spurn eftir ákveðnu hráefni með tiltekna eiginleika, hvort sem um er að ræða ákveðin gæði eða tímasetningu afhendingar. Petta markaðsfyrirkomulag í norskum sjávarútvegi leiðir augljóslega til veikingar á markaðsvirkni.

Eins og áður hefur komið fram er fiskur verulega misleit vara par sem virði ræðst af eiginleikum. Nokkur munur er pó milli fisktegunda hve mikilvægir eiginleikar eru m.t.t. virðis. Jafnframt er kostnaður við að mæla og staðfesta eiginleika ólíkur fyrir ólíka eiginleika. Líklegt er að fisktegundir sem búa yfir fáum auðmælanlegum eiginleikum séu minna viðkvæmar fyrir ofangreindum markaðsbresti en fisktegundir sem búa yfir mörgum tormælanlegum eiginleikum. Gott dæmi um petta er mikill munur á botnfiski og uppsjávarfiski par sem fyrri flokkurinn hefur marga tormælanlega eiginleika, en sá síðari fáa og auðmælanlega. Verðaðgreining er pví mun algengari fyrir porsk, ýsu og ufsa, heldur en síld og loðnu.

Margar leiðir eru til að bregðast við upplýsingavanda sem pessum. Ein leiðin er að koma á markaðsfyrirkomulagi sem dregur úr vandamálum sem tengjast ósamhverfum upplýsingum. Petta getur t.d. átt við um fiskuppboð par sem upplýsingaflæði er tryggt. Önnur leið er lóðrétt sampætting, par sem mögulegt er að viðhalda upplýsingum um vöruna alla leið til kaupanda fiskafurðarinnar. Fiskuppboð hafa öðlast tryggan sess í viðskiptum með fisk hér á landi frá pví saga peirra hófst á miðjum níunda áratugnum. Jafnframt hefur lóðrétt sampætting fyrirtækja aukist í sjávarútvegi undanfarin ár (Hagfræðistofnun, 2011). Pessi próun hefur verið möguleg vegna pess frjálsræðis sem hér hefur ríkt. Samanburðurinn við Noreg, par sem viðskiptin eru háð mun stífari takmörkunum, getur pví gefið vísbendingu um hve miklu máli gæði upplýsingaflæðis í virðiskeðjum skiptir. Hér verður reynt að varpa ljósi á pað með beinum samanburði á afkomupróun í sjávarútvegi hér á landi samanborið við Noreg.

Niðurstöður rannsókna á verðmætasköpun í íslenskum sjávarútvegi og virðiskeðju bolfisks hafa náð að draga fram tvo af peim premur páttum sem virðast skipta sköpum um hagkvæmni virðiskeðjunnar hérlendis (Knutsson, Klemensson og Gestsson, 2008). Peir pættir eru mikilvægi fiskmarkaða (Knutsson, Klemensson og Gestsson, 2010) annars vegar og virkni fiskveiðistjórnunarkerfisins hins vegar. Áhrif fiskveiðistjórnunarkerfisins á virkni og samstarf innan virðiskeðju bolfisks og mikilvægi óhindraðs upplýsingaflæðis hafa hins vegar lítið verið rannsökuð til pessa.

\section{Aðferðafræði}

Fyrri hluti pessarar rannsóknar byggir á eigindlegri könnun með hálfstöðluðum viðtölum við stjórnendur 17 fyrirtækja er tengjast beint markaðsstarfi íslenskra sjávarafurða. Könnunin byggir á innsæi og skilningi viðmælenda og hefur pann tilgang að greina viðhorf peirra við viðfangsefnis rannsóknarinnar (Collins og Hussey, 2003). Af pessum 17 fyrirtækjum eru 7 hrein markaðsfyrirtæki, p.e. fyrirtæki sem eru eingöngu í markaðssetningu á fiskafurðum en ekki vinnslu og útgerð á Íslandi. Tíu fyrirtæki er tengd eða hluti af stærri sampættum fyrirtækjum sem eru í veiðum og vinnslu. Markmiðið rannsóknarinnar 2011 er að meta markaðsáherslur í fiskveiðistjórnunarkerfinu og hvaða áhrif pær áherslur hafa á verðmætasköpun í íslenskum sjávarútvegi. 
Viðtölin voru ýmist tekin í gegnum síma eða beint við viðmælendur par sem pví var við komið. Áherslan í viðtölunum var á að viðmælendur notuðu eigin orð til að lýsa viðhorfi sínu til spurninganna en um leið að tryggja að allir svöruðu sömu spurningum (Bryman, 2008). Leitað var svara á viðhorfi stjórnenda sjávarútvegsfyrirtækja til áhrifa fiskveiðistjórnunarkerfisins á próun og virkni virðiskeðju íslensks sjávarútvegs, bæði markaðs- og rekstrarhluta hans. Pá var leitast við að draga fram sýn peirra hvað varðar mikilvægi fiskveiðistjórnunarkerfisins fyrir samkeppnishæfi Íslands.

Miðað var við að lengd hvers viðtals væri á bilinu 30 til 60 mínútur og tryggt að allir viðmælendur fengju í svörum sínum a.m.k. að fjalla um fyrirframákveðin atriði. Viðtölin voru endurrituð á tölvutækt form til frekari greiningar. Við framsetningu niðurstaðna er tryggt að ekki er hægt að rekja tilvitnanir beint til viðmælenda. Greindir voru efnisflokkar í hverju viðtali fyrir sig sem og viðtölunum í heild.

Síðari hluti rannsóknarinnar beinist að samanburði á afkomupróun sjávarútvegsfyrirtækja hér á landi og í Noregi eftir að kvótakerfi voru tekin upp í löndunum tveimur. Samanburðurinn byggir á heildarafkomu veiða sem er mæld sem hlutfall EBITDA (e. earnings before interest, taxes, depreciation and amortization) af veltu í botnfiskveiðum. Gögn um afkomu eru sótt til Hagstofu Íslands (e.d.a) og Statistisk Sentralbyrå (e.d.) og ná elstu gögnin aftur til upphafs áttunda áratugarins.

Reynt er að rýna í ástæður mismunandi próunar afkomu með pví að greina próun meðalútflutningsverðs ólíkra vöruflokka og er par annars vegar stuðst við pröngt skilgreindar vörur samkvæmt tollskrám landanna tveggja og hins vegar próun samsetningar fiskútflutnings landanna.

Vöruútflutningur hefur verið skráður í Hagskýrslur Íslands frá árinu 1914. Árið 1988 voru stöðluð tollskrárnúmer tekin upp. Pó svo kaflaskipting tollskráa sé eins hér á landi og í Noregi er nokkur munur á einstökum undirflokkum. Jafnframt eru sumir vöruflokkar sundurliðaðir á ítarlegri hátt hér á landi en í Noregi og svo öfugt. Til dæmis skiptust blautverkaðar porskafurðir (Tollskrárkafli: 0305-62XX) í ellefu undirflokka hér á landi en enga sundurliðun er að finna í Noregi. Einingaverð eru metin sem verðmæti útflutnings deilt með útfluttu magni. Allt verð eru umreiknað í USD $/ \mathrm{kg}$. Gögn um gengi gjaldmiðla eru sótt til Seðlabanka Íslands og er miðað við meðalgengi árs í útreikningum (e.d.).

Gögn um samsetningu útflutnings eru einungis til í mjög grófri sundurliðun. Pau gögn eru annars vegar sótt til Hagstofu Íslands (e.d.b) og hins vegar til Norvegian Seafood Counsil (e.d.).

\section{Próun í sjávarútvegi}

Áhugavert er að skoða próun íslensks sjávarútvegs síðan settar voru á framseljanlegar aflahlutdeildir árið 1991. Mikil sampjöppun hefur átt sér stað í sjávarútvegi bæði í veiðum og vinnslu. Í veiðum hefur togurum fækkað um 46\% frá 1992 til 2011. Mesta sampjöppun í veiðum má sjá hjá fimm stærstu aflahlutdeildarhöfum en peir réðu 17\% aflahlutdeilda 1995 en 35,17\% árið 2011.

Mikil fjölgun varð á smábátum frá árinu 1984 til 1990 er smábátum fjölgaði úr 1.060 í 2.045 báta. Á pessum árum voru bátar undir 10 brl. ekki bundnir aflamarki og pví sókn frjáls. Afli smábáta jókst gríðarlega á pessu tímabili, fór úr pví að vera 3,3\% af heildarporskafla árið 1982 í 13,8\% hlutdeild fiskveiðiárið 1991/1992. Á sama tíma hafði afli stærri skipa/báta 
dregist saman. Til að stemma stigu við offjölgun smábáta og mikilli aukningu peirra í hlutdeild porskafla voru allir bátar frá 6-10 brl. settir á aflamark frá og með fiskveiðiárinu 1991. Smábátar undir 6 brl. gátu pá valið um að fara undir aflamark eða vera bundnir svokölluðu krókaleyfi, sem í raun var frjáls sókn, með 80 banndögum á ári. Fjöldi leyfa var pannig fastsettur. Upp úr pví fór smábátum fækkandi og voru peir 1.471 árið 1997. Í kjölfar pess að lög um strandveiðar voru sampykkt má enn á ný sjá merki um fjölgun smábáta. Petta tengist beint sóknarstýringarkerfinu öfugt pví sem gerðist innan aflamarkskerfisins. Fjöldi smábáta (opnir fiskibátar) var 700 árið 2008 en hafði árið 2011 aukist um 133 eða í 833 báta. Á sama tíma hafði öðrum skipum fækkað úr 829 skipum í 818 skip.

Svipaða próun má sjá í vinnslu sjávarafurða. Pegar fjöldi vinnsluleyfa er skoðaður pá hefur peim fækkað mikið frá 1992, frá pví að vera 402 í að vera 275 árið 2007. Á pessum tíma hefur leyfum til saltfiskvinnslu fækkað um 97, til frystingar um 46, til sjófrystingar um 58 en 27 leyfa aukning hefur orðið til vinnslu á ferskum fiski. Ætla má að í mörgum tilfellum hafi sampjöppun orðið meiri í vinnslunni en pessar tölur gefa til kynna par sem hér er stuðst við vinnsluleyfi en sum fyrirtæki hafa mörg vinnsluleyfi.

Pessari sampjöppun hefur einnig fylgt breyting í virðiskeðju sjávarútvegs par sem fyrirtækin eru orðin stærri og meira um að fyrirtæki nái yfir öll prep í virðiskeðjunni p.e. veiðar, vinnslu og markaðssetningu. Afnám útflutningsleyfa á níunda áratugnum (pau síðustu 1997) ásamt stækkandi fyrirtækjum ýtti undir próun pess efnis að sjávarútvegsfyrirtæki sæju sjálf um sölu á eigin afurðum í stað stóru sölusamtakanna. Dæmi um petta er að af 10 stærstu sjávarútvegsfyrirtækjunum árið 2011 sem hafa 55,42\% af heildarkvóta eru pau öll lóðrétt sampætt p.e. pau spanna allt frá veiðum til markaðssetningar (sjá mynd 1).

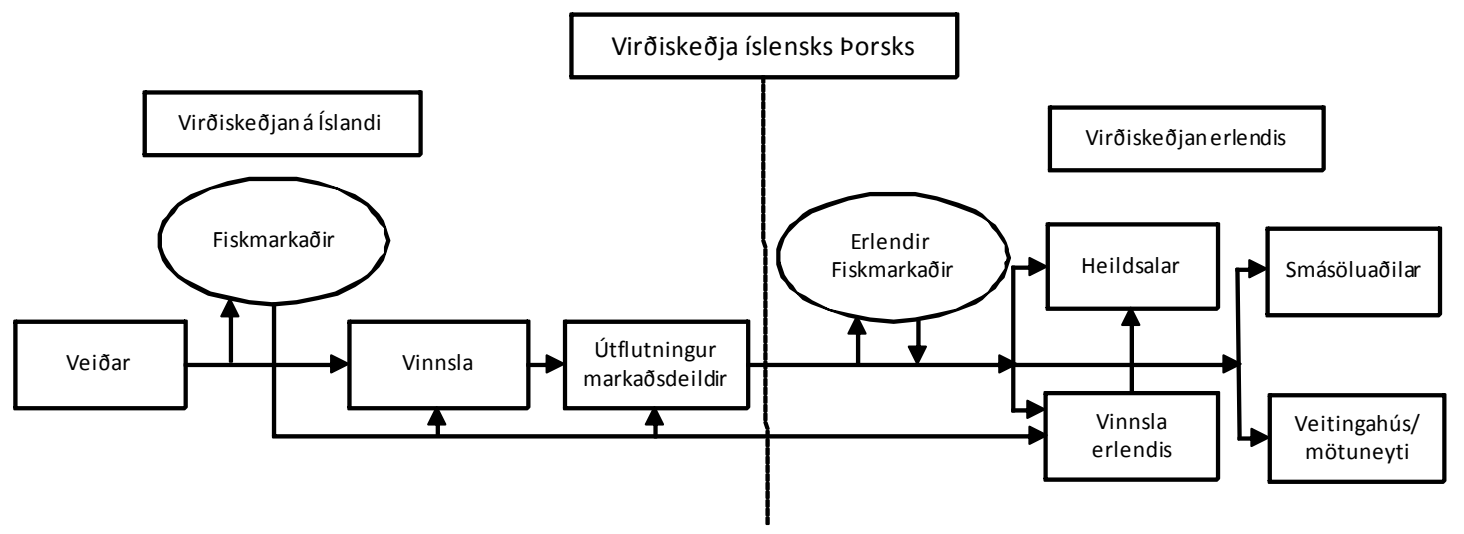

Mynd 1. Virðiskeðja porsksveiða, -vinnslu og markaðssetningar

Í rannsókninni frá 2008 (Knutsson, Klemensson og Gestsson, 2008) er lögð áhersla á að greina lóðrétt sampætt sjávarútvegsfyrirtæki sem flytja út íslenskar afurðir. Niðurstöður sýna að sameiginlegt slíkum fyrirtækjum er mjög náin samvinna milli deilda, allt frá veiðum og vinnslu til útflutnings og markaðssetningar. Afurðir fyrirtækjanna eru bæði fluttar út til frekari vinnslu erlendis, sem og til erlendra dreifingaraðila og jafnvel beint til smásala. Dreifingaraðilarnir eru mjög mikilvægur hlekkur í keðjunni par sem hver framleiðandi er sérhæfður í framleiðslu á tilteknum vörum og smásalarnir vilja geta boðið upp á sem fjölbreyttast úrval með pví að vera í viðskiptum við marga sérhæfða framleiðendur. Pví er pað oft talinn góður valkostur að selja vörurnar til sjálfstæðra dreifingaraðila fremur en að stofna sín eigin dreifingarfyrirtæki. Pessi dreifingarfyrirtæki eiga oft í samstarfi við mörg íslensk fyrirtæki og eru náin samskipti par á milli. 
Prátt fyrir að hlutfallslegt lítið magn af fiski sé selt á fiskmörkuðum hafa peir mikil áhrif í virðiskeðjunni. Stóru sampættu fyrirtækin nota markaðina til að ná fram sérhæfingu og tryggja framleiðslu og góða nýtingu framleiðslutækja meðan sjálfstæðir framleiðendur nota pá til að afla meginhluta hráefnis. Fiskmarkaðir hafa pannig stuðlað að sérhæfingu í vinnslunni sem aftur hefur skilað sér í aukinni vermætasköpun (Knutsson, Klemensson og Gestsson, 2010).

Rannsóknin leiddi í ljós að ekkert eitt staðlað líkan náði yfir rekstrarskipulag allra fyrirtækjanna heldur höfðu pau í raun farið hvert sínar leiðir. Sameiginlegur práður var hins vegar náið samstarf og skilvirk miðlun upplýsinga, sem talin er nauðsynleg til að ná árangri á mörkuðum erlendis. Mest áhersla var lögð á gæði vöru, örugga afhendingu, og aðgang að góðum mörkuðum. Lykillinn að pessu er sveigjanleiki fyrirtækja sem felst í pví að geta valið pá leið eða form sem hentar peirra starfsemi sem best til að hámarka verðmætasköpun.

\subsection{Markaðsmál}

Fram til ársins 1990 var útflutningur á íslenskum fiski að mestu í höndum priggja fyrirtækja. Tvö peirra sérhæfðu sig í útflutningi á frosnum afurðum en pað priðja í útflutningi á söltuðum fiski. Útflutningsleyfum var stýrt og árið 1982 höfðu pessi fyrirtæki um 71,5\% markaðshlutdeild af heildarútflutningi fisks. Par að auki ráku pessi fyrirtæki fiskvinnslur í útlöndum. Áherslan var á magn fremur en gæði. Sem dæmi má nefna að 40\% af frosnum fiski, sem var fluttur út, voru blokkafurðir sem skiluðu aðeins um $30 \%$ af heildarútflutningsvirðinu.

Í kjölfar minnkandi afla á tíunda áratug síðustu aldar urðu breytingar á kerfinu sem miðuðu að pví að auka útflutningsverðmæti. Samvinna milli sjómanna, fiskvinnslufyrirtækja og útflytjenda jókst og betri upplýsingum um raunverulegar óskir erlendra viðskiptavina var miðlað um virðiskeðjuna. Petta leiddi til stigvaxandi aukningar í útflutningsverðmæti. Um 1990 urðu einnig margar mikilvægar breytingar á lagaramma sjávarútvegs. Kerfi útflutningsleyfa var afnumið og fiskmarkaðir stofnaðir. Vægi stóru útflutningsfyrirtækjanna minnkaði en pess í stað spruttu upp mörg minni fyrirtæki.

Eins og komið hefur fram hefur próun undanfarinna ára annars vegar leitt til pess að fyrirtæki hafa orðið færri og stærri og pá oft á tíðum lóðrétt sampætt, og hins vegar til pess að stofnuð hafa verið smærri fyrirtæki sem hafa sérhæft sig í vinnslu og markaðssetningu virðismeiri afurða. Í stað pess að leggja áherslu á magn, hafa pau lagt enn meira upp úr pví að framleiða gæðavöru. Að mati peirra sem rætt var við í rannsókninni nefndu peir afhendingaröryggi sem einn af mikilvægustu páttum við að tryggja viðskipti:

\footnotetext{
"Kostirnir eru ótvíræðir í langtímahugsuninni. Mjög mikilvægt er að vita hvað sé mikið veitt, hvar og hvenær er hægt að veiða pað og með pví skapa afhendingaröryggi. Kerfið gerir okkur kleift að hafa stýringu á keðjunni allt frá veiðum til markaða."
}

Viðmælendur nefndu oft að stórmarkaðir vildu versla við Íslendinga umfram t.d. norsk fyrirtæki par sem íslensku fyrirtækin gætu gert langtímasamninga sem peir gætu staðið við. Eins og einn viðmælandi orðaði pað: 
"Ég held að stærstu breytingarnar hafa verið að við höfum haft ákveðna forystu, sérstaklega i allri landvinnslu. Degar við fórum að vinna með [fiskvinnsla í ákv. sveitarfélagi] eftir að við tókum par við, pá erum við svo langt á undan samkeppnisaðilunum svo sem Noregi. Ég hér um bil hika ekki við að segja að við séum um 10-15 árum á undan. Dað sem peir hafa verið að gera í dag er að taka sinar vinnslur og véla pær upp og peir eru með sömu græjur og við en peir eru ekki með sama "mentalitetið” og fiskveiðistjórnunarkerfið er pannig hjá peim í dag að fisknum, enn í dag er rótað á land á 3 mánuðum og síðan geta peir ekkert, síðan standa pessi 2-3 flott frystihús, 2 réttara sagt flott sem eru sambærileg við pað sem við erum með hér á Íslandi. En við erum náttúrlega búnir sýna pað við kúnna okkar að peir sækja frekar til okkar pví peir vita pað að við getum staðið við að afhenda vörur i hverri einustu viku allan ársins hring."

Í rannsókninni sem framkvæmd var vorið 2009 (Knutsson, Klemensson og Gestsson, 2010) kom í ljós að lóðrétt sampætt fyrirtæki stjórna núna stærri hluta af virðiskeðjunni en fyrir 20 árum. Раð hafa pau gert með pví að taka yfir fleiri hlekki virðiskeðjunnar eins og markaðspáttinn. Sampjöppun í greininni gerir pað að verkum að færri aðilar stjórna verðmætasköpuninni en áður. Pegar útflutningsleyfi voru gefin frjáls og stóru sölusamtökin afnámu skilaskyldu framleiðslu varð tímabundin aukning í skammtímasölum par sem seljendur leituðu eftir hæsta verði. Undanfarin ár hafa framleiðendur hins vegar forðast skammtímamarkað. Í stað pess hafa peir í flestum tilfellum komið sér upp langtímasamböndum við kaupendur, samböndum sem byggja á samstarfi og trausti í beinum viðskiptum, eða eins og viðmælandi sagði um próunina síðustu 5 - 7 ár:

„Bæði [sölu- og markaðsmál eru] komin inn á gólf hjá okkur sjálfum. Gerum samninga beint við kúnna til lengri tíma. Byggjum sambandið meira við 10-15 kúnna frekar en að byggja petta upp með einum aðila [... ....]. Вæði gæðamál og framleiðslustýring eru miklu nær kröfum markaðarins en var ádur. Pað er svona stóra breytingin."

Vegna pessara beinu tengsla hefur stöðugleikinn undafarin ár verið einn af helstu kostum kerfisins eins og einn viðmælenda benti á:

„... stöðugleikinn hjá okkur hefur verið okkar aðalkostur [... ... ] Síðan fóru menn að átta sig á pví að við höfðum ákveðinn kvóta. Hvenær áttum við að veiða ýsuna, hvenær áttum við að veiða karfann. Siðan fóru menn að pæla í pessu og undirbúa að selja ádur og við höfum núna gert pað í mörg ár að ádur en karfavertíðin hefst erum við búnir að selja, gera ákveðna samninga um okkar vöru. Við petta fluttist meira og minna ákvarðanatakan heim í hérað og styrkti okkur."

Annar viðmælandi úr markaðsgeiranum benti á að kaupendur pekktu vel til kerfisins á Íslandi og teldu pað hafa yfirburði t.d miðað. við Noreg:

„Dú parft ekki nema að tala við kaupanda hjá smásöluaðila, hann pekkir alveg kvótakerfið á Íslandi og hann [viðskiptavinurinn/smásöluaðili] veit alveg hvernig pað er í Noregi. Dað er engin tilviljun að allir pessir kúnnar og pú getur raðað peim upp, að peir eru allir að kaupa á Íslandi. Deir kaupa náttúrulega líka í Noregi 
og Norðmenn hafa venjulega í bolfiski... Ég get 100\% fullyrt pað að peir fá lægra verð fyrir afurðina en við."

Petta beina samband hefur aukið mikið verðmætasköpun í íslenskum sjávarútvegi en í rannsókn Ögmundar Knútssonar (2001) á samstarfi gömlu sölusamtakanna og framleiðenda kom skýrt fram að hin beinu tengsl framleiðenda við kaupendur ýttu undir aukna verðmætasköpun. Í viðtölum kom fram að áherslan á ferskar sjávarafurðir var mjög mikil og lítið var um að verið væri að leita nýrra markaða. Enda er fjöldi kaupenda á bestu mörkuðunum takmarkaður og meira mál en margir halda að koma sér í góð viðskiptasambönd:

„Við skulum átta okkur á pví að pað eru ekki endalausir kúnnar, peir bíða ekki í
röðum. Kúnnahópurinn okkar i bitaframleiðslu, eða megnið af bitaframleiðslunni
eru kannski 8 talsins og pað i allri N-Evrópu“

Fram hefur komið að lítið er um að verið sé að auka vöruframboð. аð er pví ljóst að markaðstengsl sem byggja á trausti og öruggri afhendingu er í auknum mæli lykilatriði pess að ná árangri í íslenskum sjávarútvegi.

Fyrir 1997 er ljóst að íslenskur sjávarútvegur var drifinn áfram af veiðum og áhrifum sölusamtaka í skjóli útflutningsleyfa. Í dag er greinin mun markaðsdrifnari sem byggir á beinum tengslum framleiðenda við kaupendur. Öruggur aðgangur að hráefni með samfellu og stöðugleika í huga er forsenda markaðsdrifinnar próunar. Pannig er útilokað að markaðsdrifnar veiðar geti próast undir sóknarmarki par sem kapphlaupið um aflann verður hið ráðandi afl. Á hinn bóginn stuðla aflamarkskerfi, ef peim fylgir fullt frelsi til viðskipta með afla, mjög að markaðsdrifinni próun og hámörkun arðs.

Í rannsókninni 2008 (Knutsson, Klemensson og Gestsson, 2008) var m.a. skoðuð verðmætasköpun í íslenskum sjávarútvegi í ljósi pess hversu mikið af verðmætasköpuninni verður til á Íslandi og hversu mikið erlendis. Samanburður við eldri rannsóknir (Gudmundsson, Ashe og Nilsen, 2006) gefur vísbendingu um að hlutfallslega meira sé að verða eftir á Íslandi en áður var. Samanburður pessi er pó erfiður sökum fárra rannsókna sem hafa verið gerðar á pessu sviði.

Markaðsdrifin próun ein og sér skýrir pó ekki allt. Sampættingin hefur einnig gert fyrirtækjum kleift að hagræða í rekstri t.d. leggja skipum eða selja er aflamark minnkar.

\subsection{Verðmætaaukningu i virðiskeðju bolfisks}

Til eru ítarleg gögn um verð á íslenskum sjávarafurðum. Gögnin veita mikilvægar upplýsingar um pá hlutfallslegu verðmætaaukningu sem á sér stað við mismunandi vinnslu peirra. Útreikningarnir eru byggðir á FOB-verði frá Íslandi og fiskverði á fiskmarkaði fyrir allar afurðir nema sjófrystan fisk par sem notað er markaðsverð. Aðferðin gefur góða mynd af breytingu á verðmætaaukningu í vinnslu og útflutningi en væntanlega ekki eins góða mynd af síðasta hlekknum í vinnslu á frystum afurðum sem fer oftar en ekki fram erlendis. Niðurstöður eru sýndar í töflu 1.

Tafla 1 Hlutfallslegur verðmætaauki á hráefniskostnað porsks 


\begin{tabular}{lccc}
\hline Vinnsluaðferð & 1992-1999 & 2000-2005 & 2006-2010 \\
\hline Ferskur-heill & 67 & 45 & 34 \\
Ferskur- flök & 64 & 94 & 107 \\
Frysturílandi & 43 & 40 & 26 \\
Sjófrystur & 38 & 47 & 31 \\
Saltaður & 97 & 83 & 80 \\
\hline
\end{tabular}

Verðmætaaukinn ofan á hráefniskostnað er mun minni á frystum fiski og sjófrystum, en á söltuðum fiski og ferskum flökum. Virðisauki á ferskum heilum fiski hefur farið minnkandi og er álíka mikill á síðasta tímabilinu og á landfrystum fiski og sjófrystum. Ekki er óeðlilegt að frystingarhlutinn hafi lækkað par sem dýrustu flakabitarnir fara í ferskar afurðir. Verðmætaaukningin í ferskum flökum og flakabitum getur vart talist einkennilegt par sem sala á ferskum neytendavörum hefur aukist mjög mikið hin síðustu ár.

Viðtöl við stjórnendur sjávarútvegsfyrirtækja styðja pá tilgátu að mesta verðmætaaukning í virðiskeðju bolfisks undanfarin ár hafi verið í vinnslu á ferskum flökum og flakastykkjum. Megnið af pessum bitum hafa verið flutt til Evrópu í flugi. Með sampættingu veiða og vinnslu hin síðari ár hefur verið farin sú leið að skip fara í styttri veiðiferðir til að landa ferskari afurðum. Aukin gæði hráefnis og framfarir í vinnsluaðferðum, kælingu, skipulagningu og flutningum hefur einnig aukið hillulíf vörunnar. Pannig hefur sá möguleiki opnast að hægt er að flytja vöruna út með skipum og lækka pannig flutningskostnað. Viðmælandi sem vinnur að markaðsmálum dregur pessar áherslur vel fram:

"Allt sem heitir að búa eitthvað til fyrir "end user" eða eitthvað svoleiðis, pað er
ekki að setja eitthvað utan á hann eða. Petta er "all natural". Siððan eru pað
pakkningar. Allar nýjungar síðustu 8 ár eru hvernig við getum skorið bitana
nákvæmara, hvernig getum við verið með allt pað sem kallast að lágmarka "waste",
pað er náttúrulega lykilatriði og að við getum lengt líftíma..."

Parna kemur fram að áherslan er á ferskleika frekar en að bæta einhverju við fiskinn eins og raspi eða öðru slíku. Lítið er pannig um að fyrirtæki séu að bæta við virðisaukandi páttum í hefðbundnum skilningi virðisaukningar pví verðmætin felast í pví að viðhalda upprunalegum gæðum hráefnisins og pví felst verðmætaaukningin fyrst og fremst í niðurskurði á flökum. Til að ná fram ferskleikanum hefur mikið verið fjárfest í tækni, sem eykur afköst. Hefur mikil bylting átt sér stað úti á sjó par sem allt önnur og betri vinnubrögð eru viðhöfð í dag en voru fyrir 10 árum. Mikið er lagt upp úr ferskeika, gæðum og stuttum veiðiferðum til að jafna út sveiflur í framboði. Aðrir pættir sem viðmælendur nefndu voru að tryggja hráefni af réttri tegund og stærð bæði til pess að auka skilvirkni og til að standast betur gæða- og stærðarkröfur kaupenda.

\subsection{Stjórnun}

Að mati viðmælenda er einn mikilvægasti pátturinn við að tryggja hámarksgæði og par með verðmætasköpun að hafa stjórn á veiðum, vinnslu og markaðsmálum. Stór sampætt fyrirtæki stjórna sjálf pessu skipulagi á meðan smærri sérhæfðari fyrirtæki ná pessari sampættingu með nánu samstarfi við hráefnisbirgja og kaupendur. Pessi sampætting á 
virðiskeðjunni hefur stuðlað að pví að fyrirtæki hafa náð að stýra veiðum og vinnslu eftir upplýsingum um verð og eftirspurn á markaði eða eins og einn viðmælandi sagði:

"Að menn vita eitthvað í upphafi árs úr hverju pú ert að vinna og gera áxtlanir hvernig pú ætlar að haga veiðum. Баð eru toppar í sölunum, pú veist að pú mátt veiða svona mikið af porski og pú veist að pú selur hann mest fyrir jólin og páska og veiðir hann poí tímanlega til að koma honum á markað fyrir pessa sölutíma. Svo að vissan fyrir poí hvað pú hefur pá vinna menn út frá poí, stjórna veiðunum eftir poí."

Ljóst er að pessi kröftuga stýring á virðiskeðjunni, tengslin við markaði og markviss notkun markaðsupplýsinga eru með mikilvægustu páttunum sem gera íslenskan sjávarútveg samkeppnishæfan. Viðmælendur nefndu oft pann mun sem er á Norðmönnum og Íslendingum hvað varðar skipulag fiskveiða par sem veiðar Norðmanna eru ennpá mjög bundnar við vetrarvertíð:

„Deir [Norðmenn] eru ekkert á markaðnum núna. Peir eru bara með smotterý. Deir eru úti af markaðnum. Dannig að við drögum úr öllu í sumar [... ...] Siðan í haust pá keyrum við alveg frá 1. sept. Pá er dúndrandi gangur. Pá keyrum við eins og druslan dregur að framleiða ferska hnakka. Vegna pess að Norðmenn eru ekki á markaðnum. Svo koma jól og við eigum 1. og 2. vikuna í jan. og svo drögum við úr, poí pá koma Norðmenn og rústa markaðnum og peir gera pað í lok jan. til feb. og mars og svo eru peir úti, út af aftur. Og svo komum við og höldum alltaf okkar kúnnum. Darna er algjörlega hægt að horfa á fiskveiðistjórnunarkerfið í hnotskurn."

Annar viðmælandi kom inn á svipaða pætti og benti um leið á pann viðhorfsmun sem ræður stjórnun virðiskeðjunnar í Noregi og Íslandi:

"Við erum t.d að sjá mjög oft fall í markaðinum í upphafi árs t.d pegar Norðmenn koma inn, peir fara yfirleitt svolítið villt í sínar veiðar. Deir hafa ekki náð pessum tökum sem við höfum haft á jafnri veiði yfir árið. Deir eru ennpá svolitið mikið að pjóna veiðunum á meðan við höfum náð meira peirri hugsun að pjóna markaði. “

Stýring á virðiskeðju bolfisks hérlendis á að mörgu leyti meira skylt með stjórnun á virðiskeðju fiskeldis en villts fisks. Bent hefur verið á að eini villti fiskurinn sem er í samkeppni við norskan eldislax á markaði fyrir ferskar fiskafurðir komi frá Íslandi. Viðmælendur lögðu mikla áherslu á að til pess að mæta samkeppninni purfi pað samspil langtímahugsunar, markaðstengsla og afhendingaröryggis sem næst með stjórnun á virðiskeðjunni. Slíkt væri grundvöllur pess að tryggja viðskiptavininum rétt gæði og rétta vöru pó fleira purfi til, eins og öfluga fiskmarkaði og framsal aflaheimilda.

\subsection{Sérhæfing}

Fyrirtæki velja sér ólíka staðsetningu innan virðiskeðjunnar. Sérhæfing virðist einkenna pau fyrirtæki sem ná fram hvað mestri verðmætasköpun. Sérhæfingin er bundin ákveðnum tegundum og stærðum. Fyrirtæki sem sérhæfir sig í ferskum flakabitum úr porski vill í fæstum tilfellum mjög stóran fisk eða smáan. Slíkur fiskur er pá seldur á fiskmörkuðum og í 
staðinn keyptur fiskur sem fellur betur að vinnslunni. Á sama hátt hafa orðið til smærri fyrirtæki sem sérhæfa sig í vinnslu tegunda sem áður töldust til aukaafla sem veiddist með bolfiski. Slíkur fiskur er seldur á fiskmörkuðum og sérhæfð fyrirtæki kaupa pann fisk og vinna í verðmætari pakkningar í meira mæli en áður gerðist. Pessi sérhæfing hefur pannig ýtt undir aukna verðmætasköpun og opnað á tækifæri fyrir ný fyrirtæki að komast inn á markaði.

Fiskmarkaðir stuðla að sérhæfingu í vinnslu en framsal á aflaheimildum styður við sérhæfingu í veiðum. Sérhæfingin gerir pað að verkum að útgerðir hafa bæði aðlagað varanlegar aflahlutdeildir að veiðimynstri sínu sem og mætt pörf fyrir tilflutningi innan ársins. Viðmælendur tala oft um tilfærslur milli tegunda eins og dæmið sýnir:

„Ég tel núverandi fiskveiðistjórnunarkerfi vera mjög árangursríkt, akkúrat í pessu að menn sérhæfa sig í porski eða ýsu eða karfa eða hvað pað er. [... ...] Ég sérhæfi mig í porski og svo salta ég einhvern ufsa. Ég er sjálfur í útgerd, ég get ekki bara veitt porsk og ufsa. Ég fx ýsu og karfa og hitt og petta. Pá snýst petta um að menn eru að sérhæfa sig, eins og kerfið er sett upp í dag, að menn eru að reyna að ná sem bestum árangri í poí sem menn eru í. Menn eru kannski ekki að grauta í öllum tegundum. Fiskveiðistjórnunarkerfið eins og pað uppbyggt í dag, eins og með aflamarkið að menni geti skipt poí upp á milli sín. Ég get skipt, ég á einhverja ýsu [kvóta] og ég veiði hana ekki og ég get pá látið einhvern pann sem er í pví hafa pað og fengið porsk í staðinn. Detta virkar mjög vel eins og pað er, petta er mjög skilvirkt."

Annar viðmælandi tók dæmi um tilfærslu milli tegundaflokka, p.e. milli uppsjávarfisks og flatfisks, sem skapar bæði hagræði og skilvirkni í kerfinu;
"Já pað er náttúrulega pessi sveigjanleiki að ég er með síldarkvóta en ég er ekkert að veiða hann en ég er að skipta honum og fá grálúđu og eitthvað í staðinn og steinbít skilurðu. Раð er petta að geta unnið innan kerfisins. Баð eru aðrir sem geta sótt pessa tegundir og liggja miklu betur við að sækja pessar tegundir heldur en ég og peir geta gert petta á hagkvæmari hátt og ég er kannski betri í einhverju öđru. Ég er betri i porski og t.d. steinbit. Dannig að ég er að veiða kannski prefalt, fjórfalt magn af steinbit heldur en pað sem ég á og pá er ég að skipta við einhverja aðra sem eru með uppsjávarskip og geta veitt síld. Ég er með dálítinn kvóta í Barentshafinu en ég á ekki alveg nóg í fullan túr hjá mér á skipinu pá læe ég petta frá mér og fx pá aðrar tegundir í staðinn. Dað eru pessir hlutir, heldur en að vera að pressa mann að sækja eitthvað sem maður er ekkert góður i."

Pað var ljóst að viðmælendur sem voru í útgerð mátu framsalið sem mikinn kost sem stuðlar að sérhæfingu og eykur hagræði. аð að "grauta í öllu“ var liðin tíð og að peirra mati hafði sérhæfingin bæði í veiðum og vinnslu skilað áherslu á aukna verðmætasköpun par sem áherslan er á að hámarka pað verðmæti sem fæst úr hverju hráefniskílói.

\subsection{Sveigjanleiki}

Sveigjanleikinn sem fæst með núverandi kerfi er atriði sem margir viðmælendur nefndu sem mikilvægan pátt í að tryggja skilvirkni og hámarka verðmætasköpun. Sveigjanleikinn 
byggist fyrst og fremst á pví að fyrirtækin geta séð fyrir hvaða afla pau ráða yfir á næsta ári. Fyrirtækin geta pá stjórnað hvenær fiskurinn er veiddur og í hvaða vinnslu sá fiskur fer. Dæmi um petta má taka frá viðmælenda úr markaðsgeiranum sem ræddi um tengingu framsals og markaðsmála:

\begin{abstract}
„Pað er ekki spurning að framsalið er algjörlega nauðsynlegt í svona kerfi pví pað sýnir einn af stóru kostunum í pessu kerfi sem er sveigjanleikinn. [... ...] Detta er ofboðslega sveigjanlegt og gott kerfi. Tökum dæmi, núna um sjófrystingu sem er mjög einfalt dæmi pví pað er soldið "commodity" dæmi. Markaðurinn var allur í skralli i jan og feb og verðin alveg hörmuleg. Við erum að tala um 15-20\% mismun á skilaverði. Og hvað gerum við pá. Dá fórum við ekkert á veiðar. Núna er [ákv. togari] að koma í næstu viku (maí 2011) úr Barentshafinu og hann mun væntanlega fá um 15\% hærra miðað við ef hann hefði verið að fara á sínum venjulega tíma. Vegna pess að við höfðum pá önnur verkefni fyrir skipið. Í staðinn fyrir Norðmennina, peir eru allir búnir að klára kvótann sinn. [... ...]Ég held að pað sé ekki spurning að sveigjanleiki kerfisins hjálpar mér sem markaðsmanni."
\end{abstract}

Petta tengist líka afhendingaröryggi á vörum sem hefur mikil áhrif á val kaupenda á birgjum:

\begin{abstract}
"En pað er tvennt sem við getum boðið sem aðrir geta ekki boðið. Dað er að við ráðum hvenær við veiðum og við getum lofað að við höfum aðgang að pessum fiski á næstu árum eins og við höfum haft hann og siðan er annað sem er vanmetið í markaðsstarfi og pað er samtenging veiða og vinnslu. Dá get ég sagt að við höfum á höndunum, stýringu alveg frá pví að við ákveðum að veiða fiskinn pangað til að við afhendum hann. Við getum valið stað og stund og við höfum sveigjanleikann í pví að framleiða hann í pað horf sem hann vill. Við erum ekki háðir uppboðsmörkuðum eða leyfum hvenær við megum veiða fiskinn."
\end{abstract}

Sveigjanleikinn gerir pað að verkum að hægt er að stýra veiðum og vinnslu út frá markaðsstöðu hverju sinni og sýnir vel fram á hvað kerfið í dag er orðið markaðsdrifið í stað pess að vera veiðidrifið eins og áður var.

\title{
3.6 Skilvirkni
}

Viðmælendur telja núverandi kerfi vera mjög skilvirkt, og nefna sérstaklega að frjálst framsal og aflamark séu nauðsynleg tæki til pess ná fram sérhæfingu og sveigjanleika. Pessi tvö atriði töldu peir mikilvægust ásamt peim stöðugleika sem fæst með kvótaúthlutun. аð аð menn viti hvað peir hafi og geti skipulagt sig bæði í veiðum og vinnslu.

Nokkrir viðmælendur bentu á að búið væri að eyða bæði tíma og fjármunum í að aðlaga sig að núverandi kerfi. Kerfið virðist ná fram bæði markmiðum um verndun og uppbyggingu á fiskstofnum og gera fyrirtækjum kleift að stunda arðbæra starfsemi:

„Pau [áhrif fiskveiðistjórnunarkerfisins] eru alveg gríðarlega mikil. Ef við horfum bara aðeins aftur i tímann, núna erum við að reka 7 togara,... ... sem eru að taka uppistöðuna af bolfiskkvóta fyrirtækisins. Dessi kvóti er af 18 skipum, par af eru 9 togarar sem búið er að sameina. Detta er svona fiskveiðistjórnunarkerfið i hnotskurn. Ef aldrei hefði verið hægt að færa kvóta á milli pá værum við í staðinn 
fyrir að gera út 2 skip í að veiða porsk og ýsu pá værum við að gera út 18.9 togara, 6 stóra vertíðarbáta og einhverja nokkra minni báta. Sem pýðir pað að pú getur ekki verið með heilsársútgerð, pú getur ekki verið með neina samfellu, pú getur ekki tryggt viðskiptavini pínum pað að pú getir alltaf afhent peim vöru alveg sama hvaða árstíð er. Dað er pað sem skiptir svo miklu máli, pú nærð aldrei pessu skrefi svona nærri neytandanum nema að pú hafir tryggar heimildir, tryggar afhendingar. Að pú getir sannfxrt hann um pað að getir á öllum árstímum alltaf afhent honum vöru pegar hann parf á poí að halda. Að̈öðrum kosti pá fara peir og skipta við stóra milliliði sem eru að "sourca“ frá Noregi og Íslandi og héðan og paðan, og eru að halda lagera til pess að geta gert pað sem við erum að gera. Maður sér petta t.d mjög vel í Bretlandi, pað er ekkert langt síðan að par voru nokkur mjög stór heildsölufyrirtæki sem meira og minna allur sjófrystur fiskur fór í gegnum."

Skilvirkni kerfisins og sú hagræðing sem pað hefur náð fram kemur fram í peirri sampjöppun sem orðið hefur í greininni bæði í veiðum og vinnslu. Pessu lýsti einn viðmælandinn pannig:

"Kerfið er náttúrulega hannað til pess að reyna mjaka pví með markaðslegum aðferðum til aukinnar skilvirkni og pað er framsal annars vegar innan ársins og hins vegar varanlegt framsal. Detta var hugsað til pess að aflaheimildirnar myndu leita til peirra sem væru að gera hlutina á sem arðbærastan hátt, pá væri pað greinin sjálf sem væri að fjármagna pann tilflutning. Dað er pað sem gleymist stundum pegar verið er að horfa til pess að einhver hafi selt sig út úr greininni og grætt af poí mikla peninga pá var pað greinin sjálf sem var að borga pá peninga og jafnvel að skuldsetja sig til pess og parf pá að hafa aðganginn að kvótanum áfram til pess að geta staðið pá skil á peim skuldum. Pannig er pessi innri mótor sem menn hafa verið að nota og gera ráð fyrir að virki til aukinnar arðsemi og hagræðingar í greininni. Dað er pessi innri mótor sem menn hafa hug á pví að taka úr sambandi núna."

Að mati viðmælenda er ljóst að núverandi kerfi er mjög skilvirkt og að miklu leyti markaðsdrifið í stað pess að vera stýrt af veiðum eða framleiðslu.

\subsection{Strandveiði}

Viðmælendur tjáðu sig mikið um aðra pætti fiskveiðistjórnunar svo sem strandveiði og byggðakvóta. Peir nefndu dæmi um mismunandi gæði á strandveiðifiski og að sá fiskur væri nær algjörlega veiðastýrður í frjálsum veiðum. Bent var mikinn mun á nýtingu hans og minni verðmætum sem strandveiðifiskur skapaði miðað við fisk sem aflað væri með eigin skipum. Dæmi um mismun milli kerfanna nefndi einn framleiðandi að í júní 2010 hafi hann tekið góðan strandveiðifisk og borið saman við hráefni af eigin skipi. Strandveiðifiskurinn skilaði 41 krónum minni verðmætum á hvert hráefniskíló en aflinn af eigin skipi. Hann nefndi að petta væri góður strandveiðifiskur en almennt væri hann mjög misjafn og fiskurinn í júlí og ágúst væri oft mjög lélegur.

Ljóst er að viðmælendur í rannsókninni 2011 voru frekar neikvæðir gagnvart gæðum strandveiðifisks. Pó kom fram að sumir bátar kæmu alltaf með góðan fisk. Einnig að fiskur í maí og júní væri oft í lagi en í júlí og ágúst væri fiskurinn mun lakari. Athyglisvert er í pví 
sambandi að skoða rökstuðning (Pingskjal 609, 1989-90) sem var lagður fram á Alpingi 198990 pegar fiskveiðiárinu var breytt úr almanaksári í að vera frá 1. september til 31. ágúst. Par segir:

\begin{abstract}
"Meginkostir pessa fyrirkomulags eru að flestar vertídir eða veiðitímabil falla innan pessa ramma. Dá er slíkt fyrirkomulag til pess fallið að draga úr aflatoppum yfir sumarmánuðina, en sá fiskur hefur að öllu jöfnu nýst fiskvinnslunni illa. Pá er mikilvægt út frá allri áxtlanagerð um próun og framvindu efnahagsmála að upplýsingar um leyfilegt aflamagn liggi fyrir snemma á haustin."
\end{abstract}

Háskólasetrið á Vestfjörðum vann úttekt á framgangi og áhrifum strandveiða sumarið 2009 fyrir sjávarútvegs- og landbúnaðarráðuneytið (Háskólasetur Vestfjarða, 2010). Í peirri úttekt var rætt við smábátasjómenn sem flestum pótti fyrirkomulagið takast mjög vel og gæði aflans almennt talin mjög góð.

Matís vann leiðbeiningar um meðferð fisk fyrir smábáta (Jónas R Viðarsson, Sveinn Margeirsson og Sigurjón Arason, 2010) par sem kemur fram að lítil kæling og röng meðferð hafi mikil áhrif á gæði fisk sem fari til vinnslu. Par er bent á að:

„... oft og tíðum veldur aðstöðuleysi og pekkingarskortur pví að gæði aflans er ekki i samræmi við pær væntingar sem til hans eru gerðar pegar hann kemur í hendur kaupenda".

Eins er bent á í skýrslu Matís að:

"Afli smábáta hefur burði til að vera besta hráefni sem völ er á, par sem varla er hægt að hugsa sér ferskari fisk en afla dagróđrabáta sem veiða á línu eða handfæri"

Petta er í nokkurri andstöðu við pað sem viðmælendur í rannsókninni 2011 höfðu um málið að segja. Peir bentu á að gæði séu ekki bara ferskleiki heldur stærð, litur og ormafjöldi. Einnig að stöðuleiki á framboði teljist til gæða.

Við skoðun á umfjöllun um strandveiði má vera ljóst að sjónarmið eru mjög misjöfn og mikil pörf að vinna rannsókn á ýmsum áhrifapáttum, svo sem á gæðum, hverjir stunda veiðarnar, hvernig fiskurinn nýtist, verðmætasköpun, afkomu og byggða- og atvinnuáhrifum veiðanna.

\title{
4 Samanburður við Noreg
}

Pegar rekstraryfirlit sjávarútvegsfyrirtækja fyrir undangengna áratugi eru skoðuð kemur vöxtur virðisauka innan greinarinnar fram með skýrum hætti. Hugtakið virðisauki (e.value added) lýsir mismun framleiðsluvirðis og aðfanga. Hægt er að mæla vergan eða hreinan virðisauka, p.e. fyrir eða eftir hlut fjármagns. Раð er ekki gert hér heldur er í pessari greiningu stuðst við EBITDA, rekstrarhagnað fyrir afskriftir, fjármagnsliði og skatta. Til að auðvelda samanburð er hlutfall EBITDA af veltu notað sem mælikvarði. Áherslan er á arðsemi botnfiskveiða. Mynd 2 sýnir próun EBITDA hlutfalls af veltu í botnfiskveiðum á Íslandi og í Noregi ásamt muninum á hlutfallinu milli landana (Ísland-Noregur). 


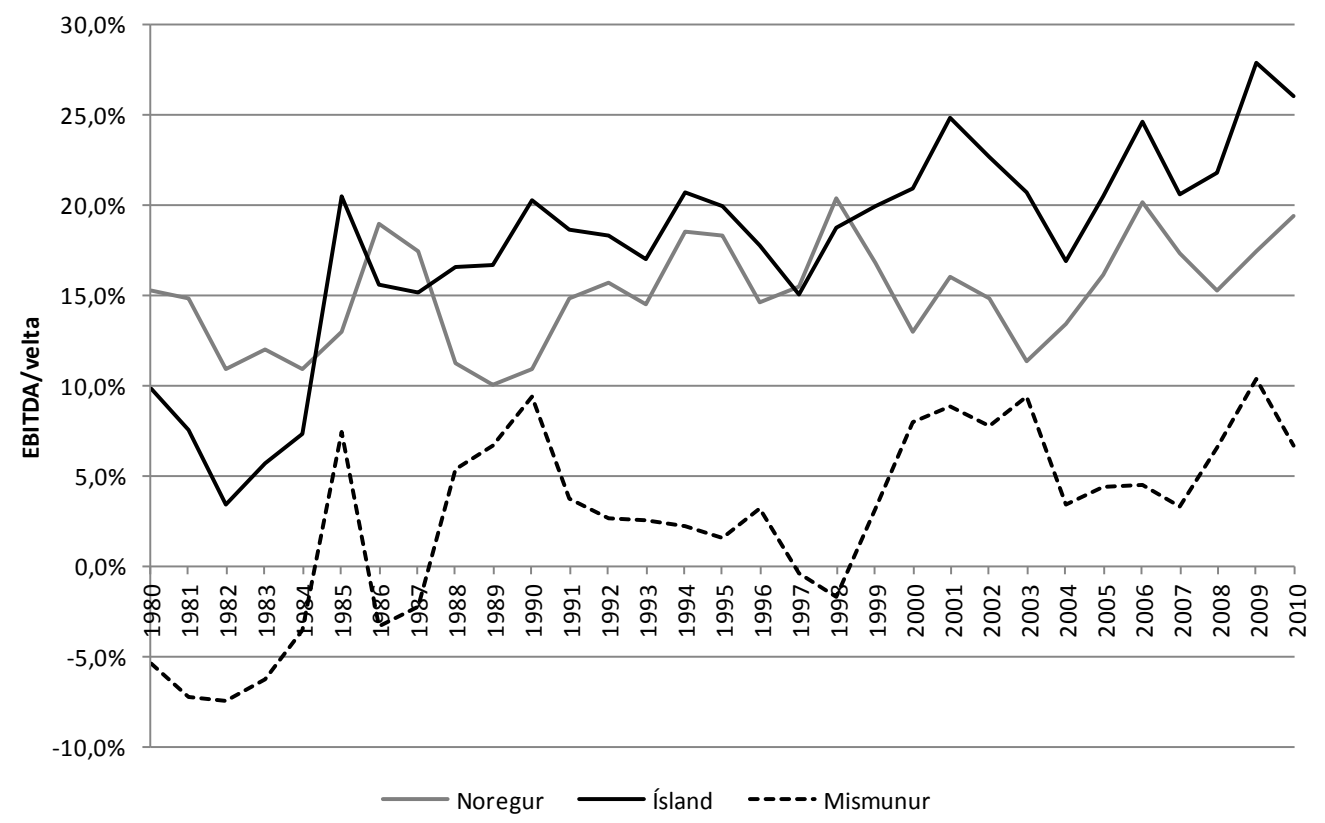

Mynd 2: Próun EBITDA hlutfalls af veltu í botnfiskveiðum á Ísland og Noreg, 1980-2010

Afkoma í botnfiskveiðum, bæði á Íslandi og í Noregi, var erfið framan af níunda áratugnum. Glögglega má sjá próun í átt til betri afkomu frá miðjum níunda áratuginum á Íslandi. Sú próun hefur reynst nokkuð samfelld hér á landi, en hlutfall EBITDA hagnaðar af tekjum hefur vaxið um $0,48 \%$ á ári hér á landi en um 0,14\% á ári í Noregi að meðaltali. Greinilegt er að arðsemi hérlendra botnfiskveiða hefur vaxið umtalsvert samanborið við Noreg. Í báðum löndunum voru tekin upp kvótakerfi á tímabilinu, á Íslandi 1984 og í Noregi 1990. Ólíklegt er pó að áhrifa peirra taki að gæta að marki fyrr en upp úr miðjum tíunda áratugnum.

Sé mismunur hlutfallsins greindur frekar kemur berlega í ljós hve mikill pessi munur er og hvernig hann hefur próast. Á níunda áratugnum var munurinn að meðaltali $-1,6 \%$, p.e. Íslandi í óhag. Á tíunda áratugnum var hann að meðaltali 2,6\% og tölfræðilega marktækt frábrugðin 0\% við 1\% mörk samkvæmt t-prófi. Eftir aldamót var hann 6,6\% að meðaltali og marktækur við 0,1\% mörk samkvæmt t-prófi. Niðurstöðurnar benda til pess að arðsemi hafi batnað til mikilla muna í íslenskum botnfiskveiðum samanborið við norskar og sé nú marktækt meiri að jafnaði en par í landi.

Svipuð niðurstaða fæst sé litið til arðsemi á magneiningu. Mynd 3 sýnir samanburð á EBITDA á hvert veitt kg, mælt í USD/porskígildiskíló. Porskígildin eru reiknuð útfrá 


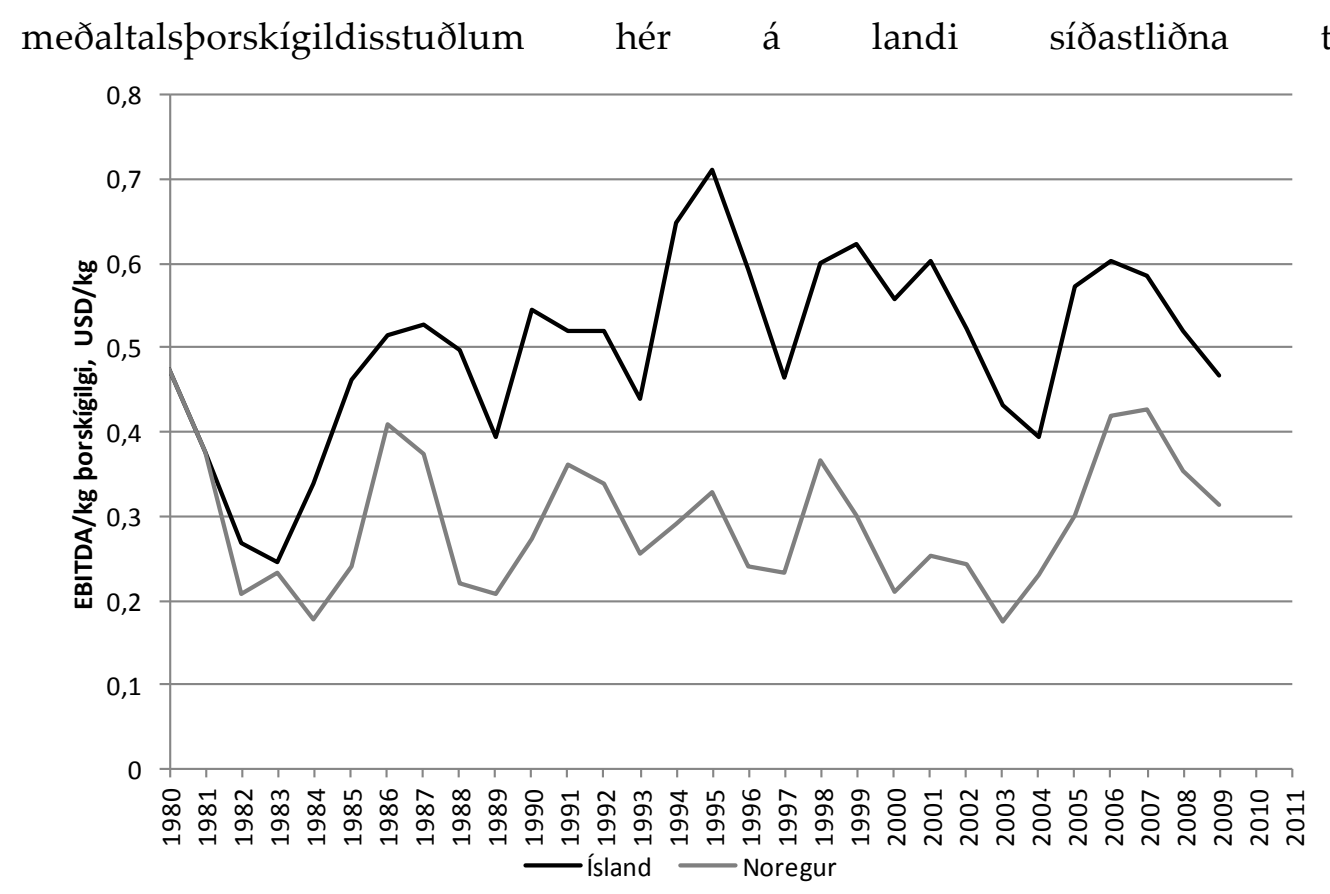

Mynd 3: Próun EBITDA á kg. porskígildis í botnfiskveiðum á Ísland og Noreg, 1980-2009

Mynd 3 sýnir með enn skýrari hætti pá tilhneigingu sem sjá mátti á mynd 2. Frá miðjum áttunda áratugnum hefur arðsemi útgerðar verið að batna hér á landi miðað við próunina í Noregi.

Mikilvægt er að undirstrika að pessi próun á sér stað á sama tíma og íslenskar veiðar eru að dragast mun meira saman en norskar, svo skýringanna er ekki að leita í auðlindinni. Í ljósi pess að bæði löndin búa við svipaða aflasamsetningu, svipað tæknistig í veiðum og hliðstæð fiskveiðistjórnunarkerfi, virðist vart hægt að leita skýringanna í öðru en ólíkri getu til að skapa verðmæti úr peim afla sem landað er eins og svo glöggt sést á mynd 3.

Forvitnilegt er að velta fyrir sér hvað skýrir pessa próun. Ýmsar skýringar eru mögulegar. Í fyrsta lagi er hugsanlegt að íslenskur fiskur sé álitinn betri en norskur. Рað ætti að lýsa sér í hærri einingaverðum fyrir sambærilegar vörur. Hins vegar gæti íslensk fiskvinnsla verið hæfari að framleiða pá vöru sem gefur af sér mestan arð. Рað ætti að lýsa sér í ólíkri próun afurðasamsetningu í löndunum tveimur. Hvoru tveggja verður gefinn gaumur hér að neðan.

Fyrst verður hér hugað að próun á verði ólíkra afurða. Til að losna við truflandi áhrif gengis er greiningin byggð á hlutfallslegum verðum, p.e. niðurstaðan gefin upp sem hlutfallið milli einingaverðs á íslenskum fiski samanborið við norskan. Stuðst er við markaðsgengi við útreikningana. Reynt er eftir fremsta megni að skilgreina vörur nægilega pröngt til að verðsamanburður sé raunhæfur.

Mynd 4 sýnir hlutfallslegt verð á frosnum flökum af íslenskum porski, ýsu og ufsa á móti norskum. 


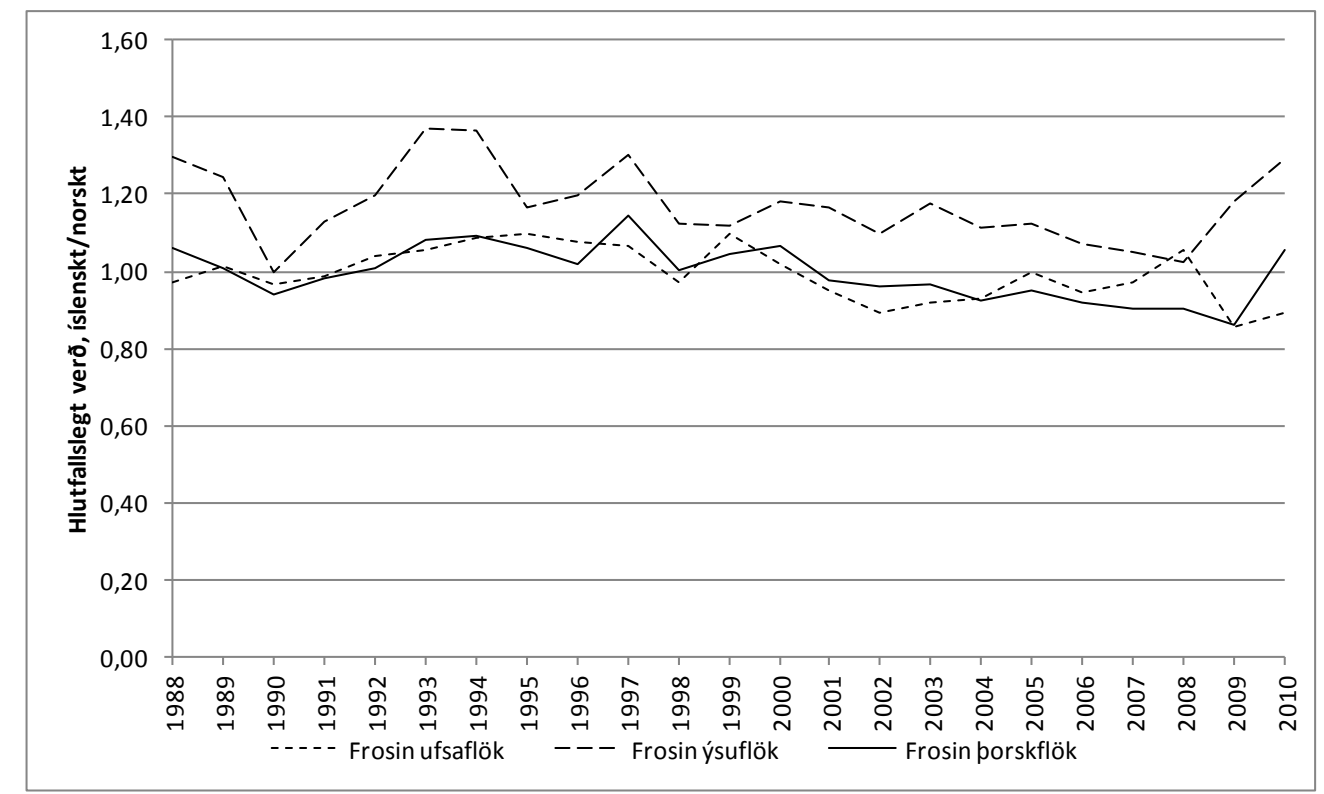

Mynd 4: Hlutfallsleg einingaverð á frosnum íslenskum flökum af porski ýsu of ufsa á móti norskum frá 1988-2010.

Ekki er hægt að segja að myndin sýni sannfærandi stöðugan mun á einingaverðum fyrir porsk eða ufsa, sem skýrt gæti mismunandi arðsemi. Meðaltal hlutfallslegs verðs er 1,06 fyrir porsk og 0,99 fyrir ufsa. Verðið virðist sveiflast kringum 1 og fylgja svipuðu mynstri og gengi krónunnar, p.e. hærra verð á tímabilum veiks gengis (um miðjan tíunda áratuginn og síðustu ár) og lægra verð á tímabilum sterks gengis (um miðjan síðasta áratug). Á hinn bóginn er verð á ferskri ýsu umtalsvert hærra (meðaltal 1,17, marktækt frábrugðið 1 fyrir p<0,001) sem gæti skýrt að hluta betri arðsemi hér á landi. Hliðstæð mynd fæst sé litið til ferskra flaka (Mynd 5).

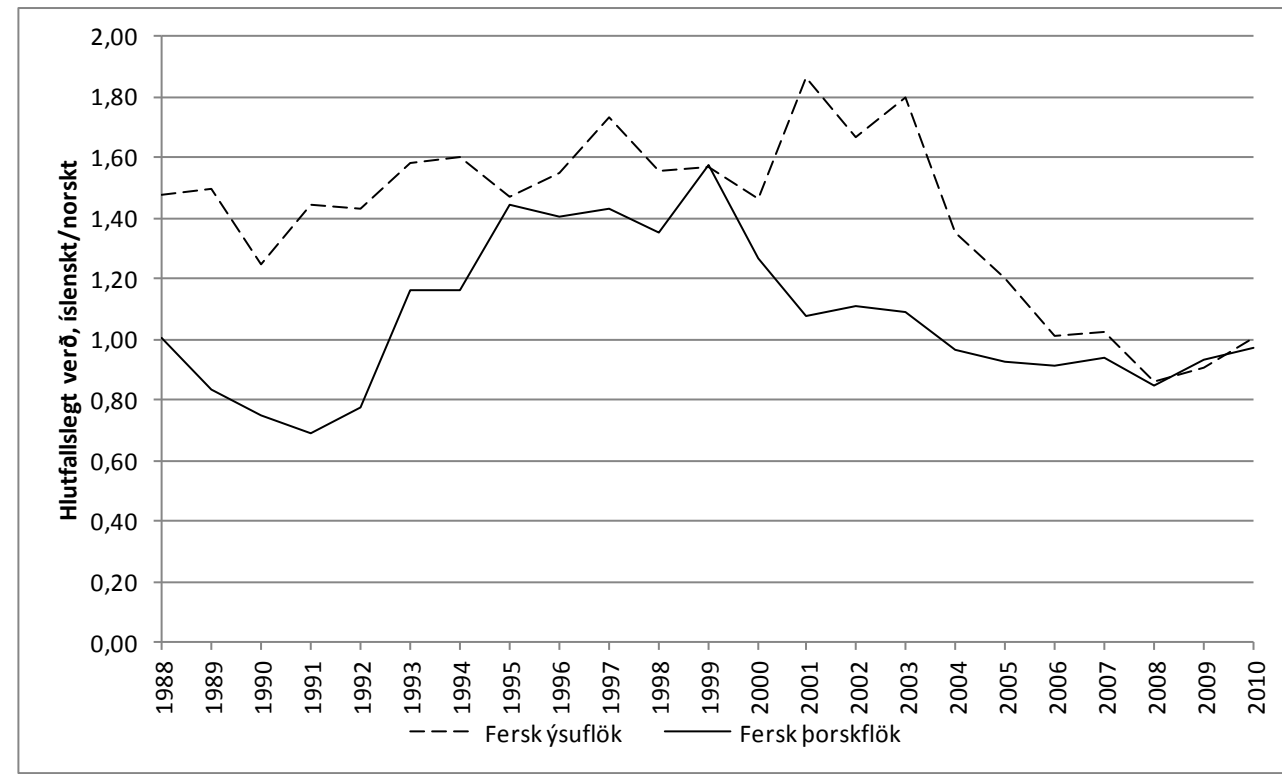

Mynd 5: Hlutfallsleg einingaverð á ferskum íslenskum flökum af porski og ýsu móti norskum frá 1988-2010. 
Á mynd 5 koma fram svipaðar niðurstöður og sáust á mynd 4 hvað varðar bæði porsk og ýsu. Meðan porskafurðir hafa sveiflast í kringum sama einingaverð hefur verð á íslenskri ýsu verið nokkuð hærra en á norskri. Mynd 6 sýnir hliðstæða niðurstöðu fyrir nokkuð víðar skilgreinda flokka af afurðum undangenginn rúman áratug.

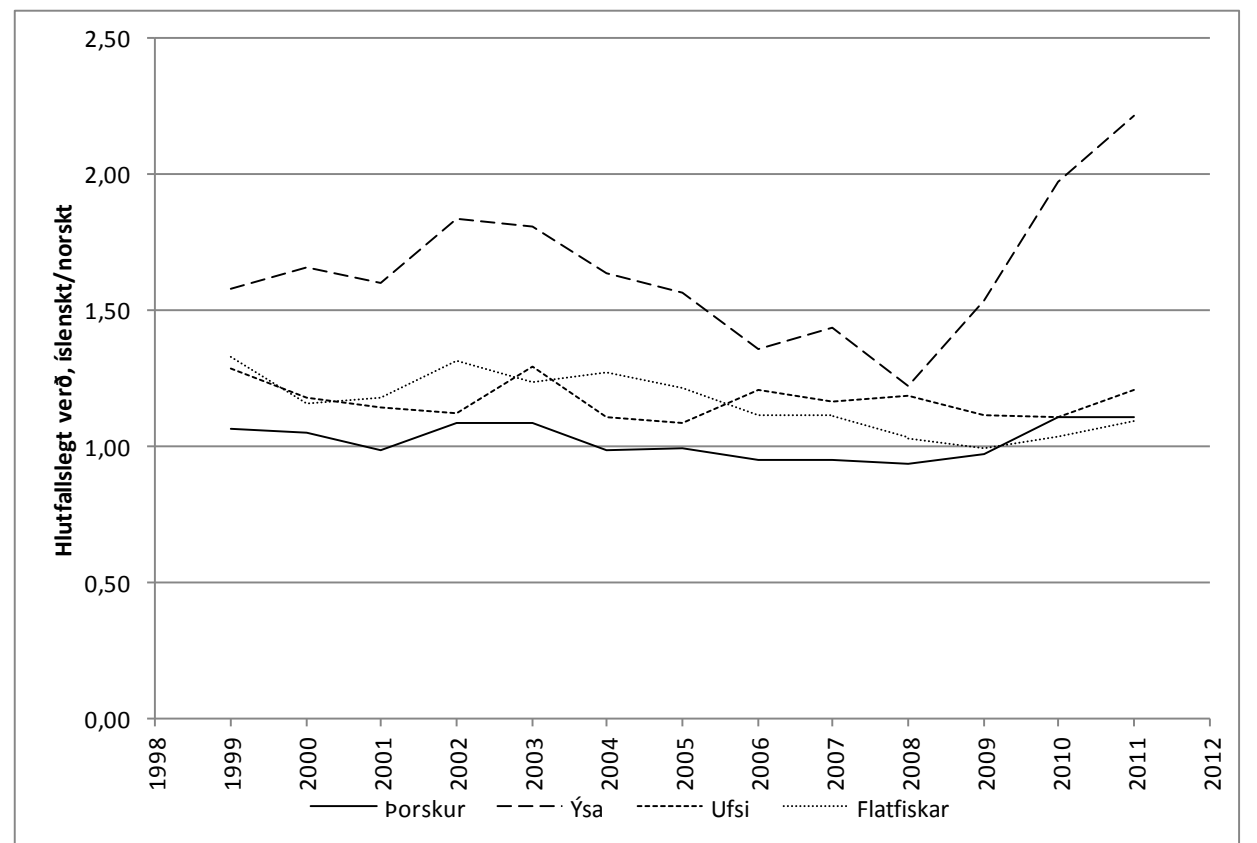

Mynd 6: Hlutfallsleg einingaverð á öllum afurðum (vegið meðaltal) af íslenskum porski, ýsu, ufsa og flatfiski móti norskum frá 1999-2011.

Mynd 6 sýnir sömu mynd og áður fyrir porsk. Hlutfallslegt verð porskafurða er mjög svipað hér á landi og í Noregi. Sama er ekki að segja um minni tegundir, s.s. ýsu, ufsa og flatfisk, par sem hærra verð næst að jafnaði fyrir pessar fisktegundir hér á landi. Hluti skýringarinnar á betri afkomu gæti pví leynst í betri nýtingu á umfangsminni tegundum og meðafla.

Næst er skoðuð samsetning út frá skiptingu í frystar, saltaðar og ísaðar afurðir. Myndir 7 og 8 sýna próun á afurðasamsetningar hér á landi síðan 1980 og í Noregi síðan 1988.

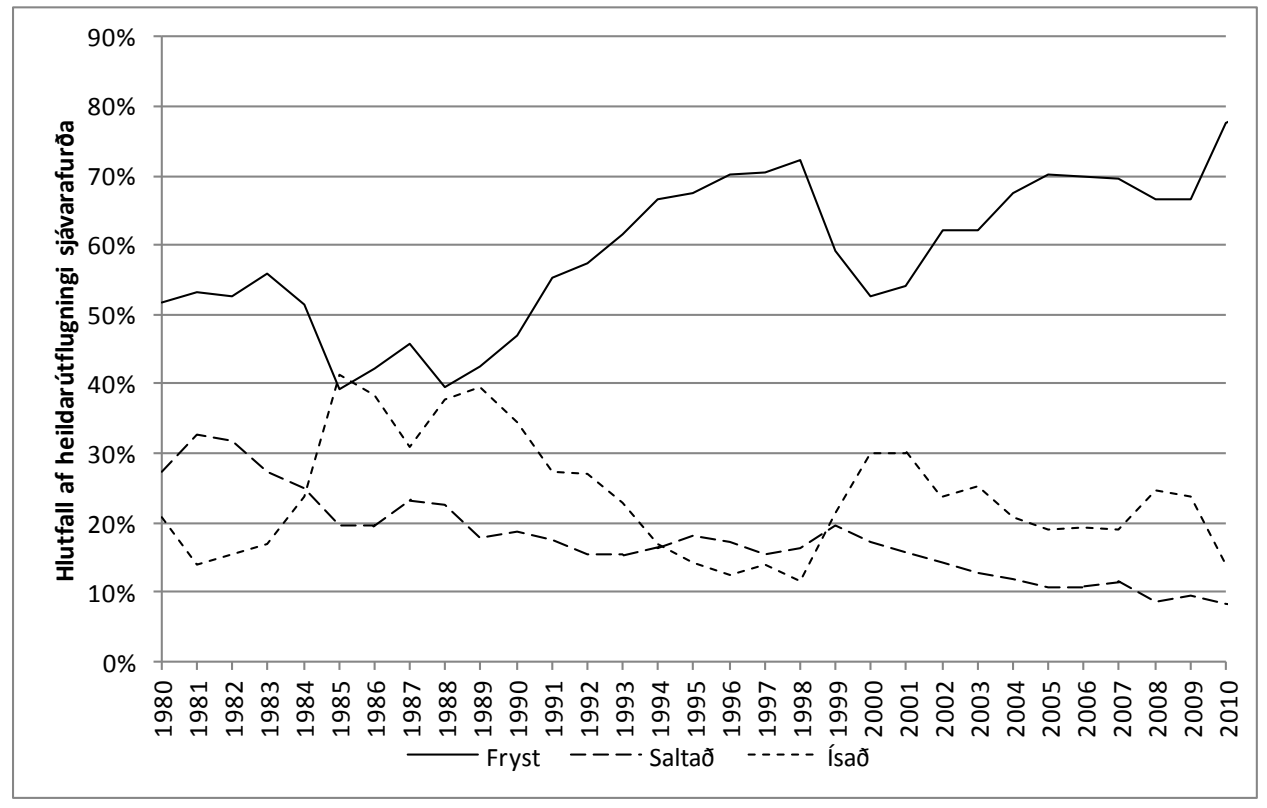


Mynd 7: Hlutfallsleg samsetning fiskútflutnings á Íslandi frá 1980-2010.

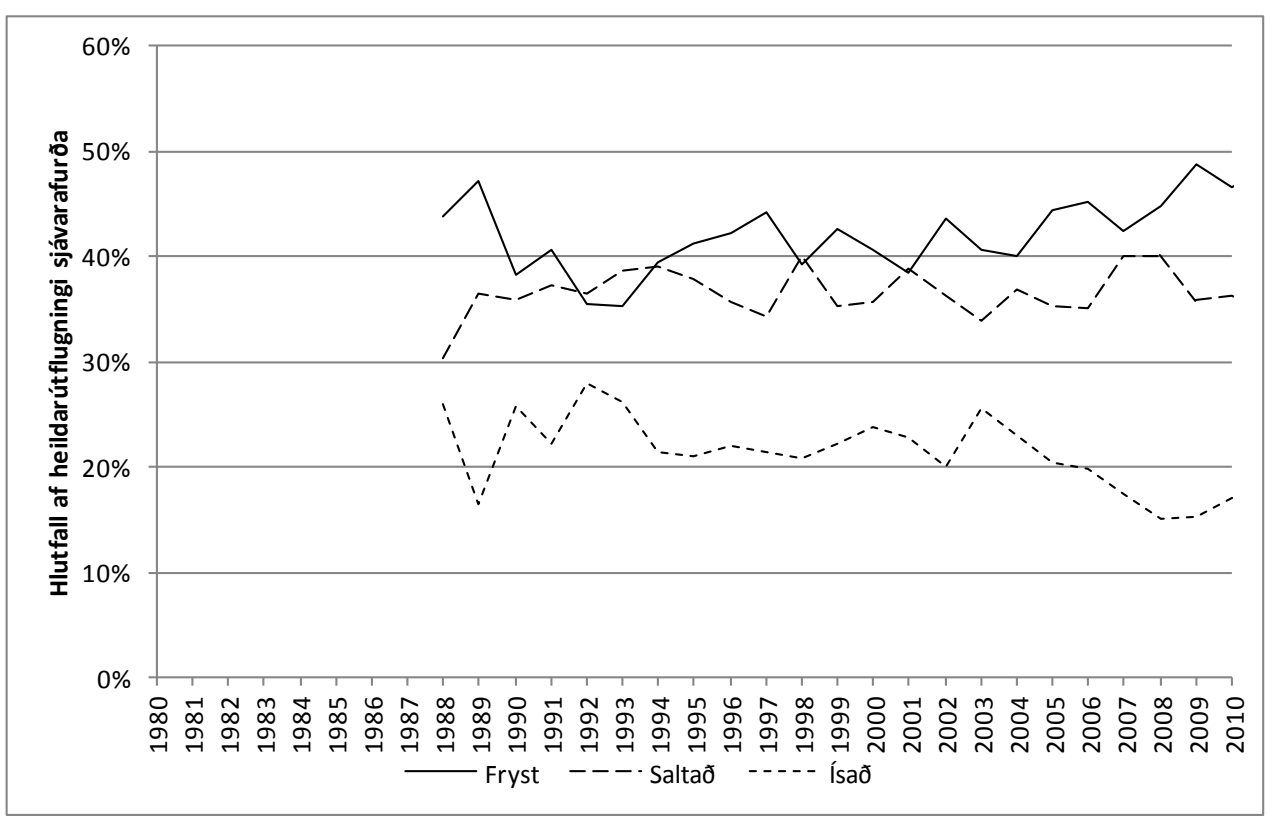

Mynd 8: Hlutfallsleg samsetning fiskútflutnings í Noregi frá 1988-2010.

Eins og sjá má eru myndirnar um margt ólíkar. Í fyrsta lagi hefur afurðasamsetning breyst mun meira hér á landi en í Noregi. Einnig er breytileiki samsetningarinnar mun meiri hér á landi en par. Petta bendir til meiri sveiganleika og virkara markaðskerfis hér á landi samanborið við par. Myndir 9 og 10 sýna nánar hvernig próunin hefur verið varðandi tvo mikilvæga flokka, fersk botnfiskflök og saltfisk.

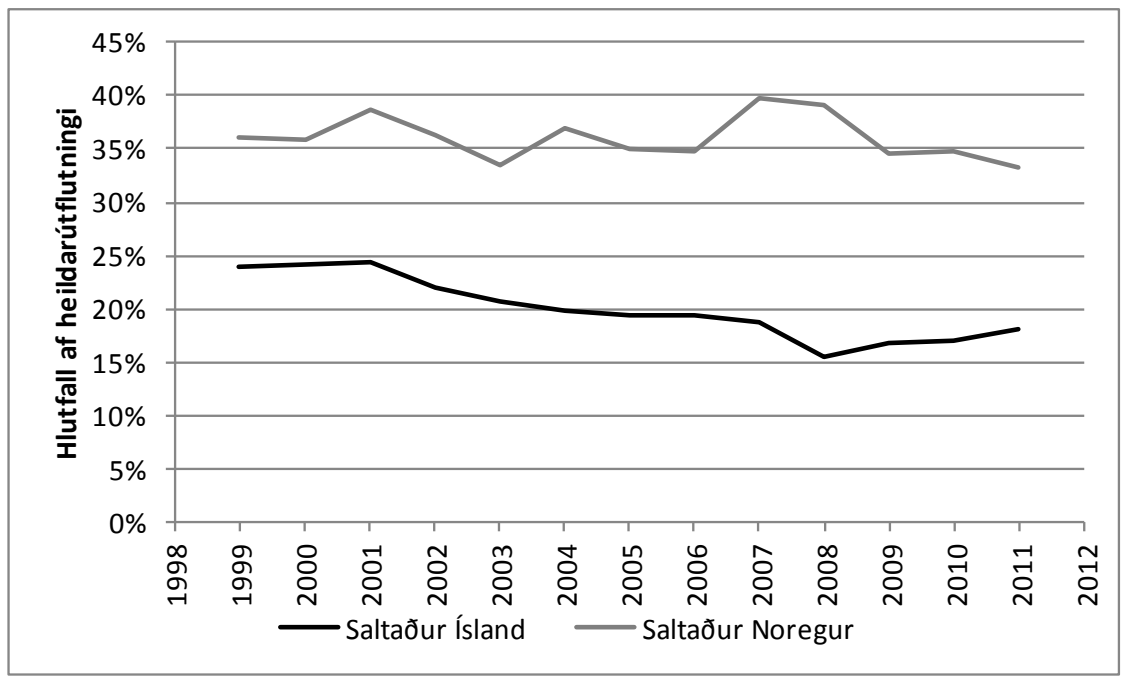

Mynd 9: Hlutfall saltfisks í fiskútflutningi á Íslandi og í Noregi frá 1999-2011. 


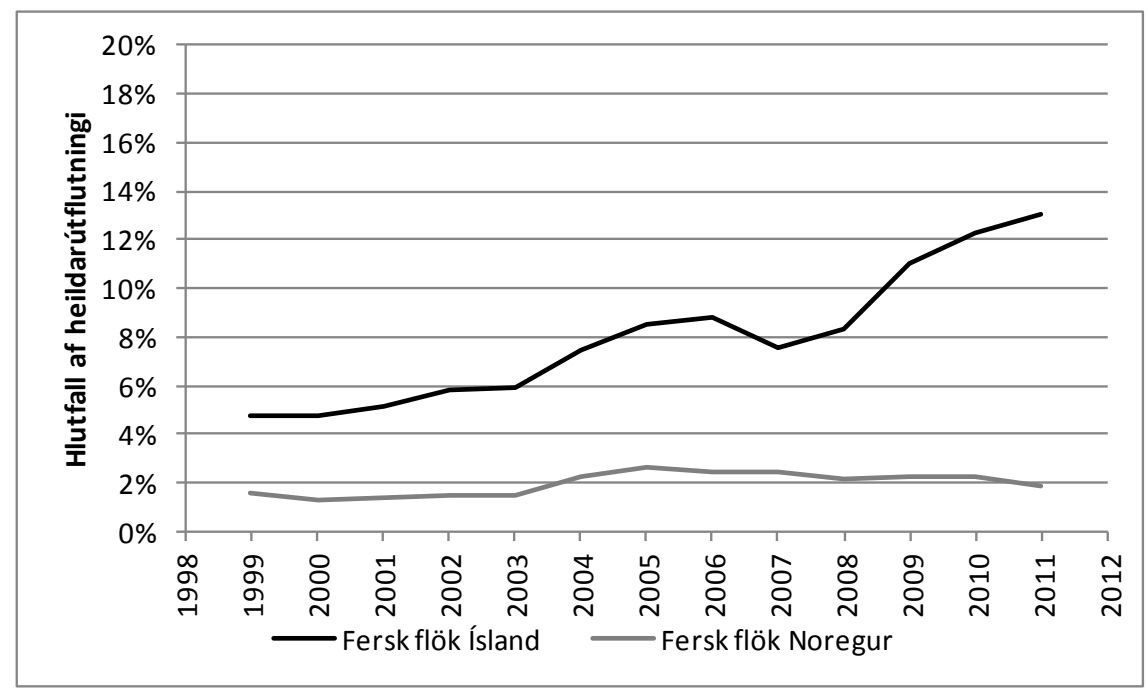

Mynd 10: Hlutfall ferskra flaka í fiskútflutningi á Íslandi og í Noregi frá 1999-2011.

Myndir 9 og 10 sýna hvernig útgerðin hér á landi hefur aðlagað afurðasamsetningu sína að breyttum skilyrðum með pví að hverfa frá saltfiskvinnslu og auka útflutning á ferskum flökum. Mynd 10 sýnir vel pá miklu aukningu sem orðið hefur á útflutningi ferskra flaka frá Íslandi par sem flutningur með flugi hefur aukist mjög. Pessi aukning hefur að hluta verið á kostnað útflutnings á heilum fiski í gámum. Bæta mætti enn við pessa umfjöllun með að sýna t.d. hve frábrugðin samsetning á frosnum afurðum hér á landi er miðað við Noreg. Hér er meginuppistaðan flök en par er megin uppistaðan heill frosinn fiskur til áframvinnslu erlendis, og er sá útflutningur Norðmanna vaxandi á kostnað flaka. Sama gildir um ferskan fisk hér hefur verið aukning í útflutningi á flökum á kostnað heils fisks og er petta er einn megin munurinn á milli Íslands og Noregs.

\section{Niðurstöður}

Á undanförnum árum hefur sjávarútvegurinn getað nýtt pau tækifæri sem hafa falist í aðlögun að fiskveiðistjórnunarkerfi sem hefur pað markmið að hámarka verðmætasköpun og hagræði innan greinarinnar. Greinin hefur sjálf stýrt aukinni skilvirkni með hagræðingu sem leitt hefur af sér fækkun skipa, sampjöppun aflaheimilda, aukna sérhæfni, skipulagsbreytingar og aukna tæknivæðingu. Áhrif breytinga sem gerðar hafa verið á kerfinu verða sjaldnast sýnilegar fyrr en að loknum aðlögunartíma sem getur varað í nokkur ár.

Sú spurning sem hér hefur verið tekist á við snýst um samspil fiskveiðistjórnunar og skipulags markaðsmála og pað hvernig pessir pættir saman stuðla að aukinni arðsemi í sjávarútvegi. Greiningin hefur byggt á tveimur meginstoðum. Annars vegar er byggt á viðtölum við aðila í fiskiðnaði og útgerð. Hins vegar er byggt á samanburði við Noreg, par sem einnig er við lýði kvótakerfi en skipulag markaðsmála hefur einkennst af miðstýringu.

Niðurstöðurnar eru mjög á einn veg. Kvótakerfið og frjálsræði í markaðsmálum hefur skapað markaðsdrifin sjávarútveg, sem aðlagar sig breytingum á aðstæðum, finnur nýja markaði og hagar skipulagi í rekstri með pað аð markmiði að sinna viðskiptavinum með besta mögulegum hætti. Petta staðfesta viðtöl við markaðsaðila. Glögg merki pessa má einnig sjá á peim sveiganleika í vörusamsetningu og getu til að skapa verðmæti úr minni tegundum sem haggögnin sýna. Samanburðurinn við Noreg er sláandi í pessu samhengi. Par 
sést sjávarútvegur sem enn er veiðidrifin, með afurðasamsetningu sem endurspeglar áherslu á afköst og geymslupol fremur en parfir kaupenda. Markaði með slíkar vörur hefur íslenskur sjávarútvegur valið að gefa eftir og nýtt sér fremur pá markaði par sem kostir markaðsdrifinna virðiskeðja koma best að notum. Sýnt hefur verið fram á að íslensk sjávarútvegsfyrirtæki hafa ekki myndað eitt í staðlað skipulagsform í virðiskeðju sem hentar öllum fyrirtækjunum jafn vel, heldur hefur sveigjanleiki og aðlögunarhæfni fyrirtækja í greininni geri peim kleift að staðsetja sig á mismunandi og ólíkan máta innan virðiskeðjunnar.

Erfitt er að áætla hversu miklum ábata markaðsdrifinn sjávarútvegur skilar umfram veiðadrifin sjávarútveg. Pær niðurstöður sem hér hafa verið birtar benda pó til pess að um verulegar fjárhæðir sé að ræða. Benda má á að niðurstöðurnar sem fram koma í mynd 2 benda til um 6,5 prósentustiga hærra EBITDA hlutfalls af veltu í fiskveiðum hér á landi samanborið við Noreg. Framleiðsluvirði fiskveiða hér á landi var um metið 134 milljarðar árið 2010. Ef arðsemi fiskveiða hefði verið svipuð og í Noregi má ætla að framleiðsluvirðið hefði verið 8,2 milljörðum króna minna pað ár. Með sama hætti má meta pennan mun aftur í tíman á grundvelli munarins í arðsemi milli Íslands og Noregs og vinnsluvirðis fiskveiða. Niðurstaðan gefur til kynna að samanlagður munur sé um 120 milljarðar frá 1980 á verðlagi júlí 2012.

Verðmætasköpun í íslenskum sjávarútvegi byggir á tveimur megin stoðum, Kvótakerfi sem gerir útgerðinni kleift að skipuleggja sóknina eins og henni hentar, og markaðsfyrirkomulagi sem gerir vinnslunni kleift að miðla og bregðast við kröfum viðskiptavina. Mikið af peirri verðmætasköpun í sjávarútveginum sem svo tíðrætt er um er til komin vegna fyrirtækja sem eru í stakk búin til að sinna beinum samskiptum við viðskiptavini sína og hafa getu til að bregðast við kröfum markaðarins. Petta er mikil og jákvæð breyting frá peim tíma að veiðar voru kapphlaup um sem mestan afla, útflutningi var stýrt með útflutningsleyfum og stóru sölusamtökin sáu um alla markaðssetningu íslenskra sjávarafurða. Mikilvægt er að vara við breytingum á umgjörð sjávarútvegs hér á landi, sem dregið geta úr hvata fyrirtækja til að halda í pá markaðstengingu og uppbyggingu á markaðsdrifinni virðiskeðju sem nú er til staðar. Slíkt getur augljóslega skaðað arðsemi í íslenskum sjávarútvegi með tilheyrandi tapi fyrir samfélagið. 


\section{Heimildir}

Bryman, A. 2008. Social Research Methods.3rd. ed.New York: Oxford University Press.

Collins, J. og Hussey, R. (2003). Business Research. A practical guide for undergraduate and postgraduate students. Second Edition. New York: Palgrave Macmillan.

Daði Már Kristofersson og Kyrre Rickertsen (2004) Efficient estimation of hedonic inverse input demand systems. American Journal of Agricultural Economics, 86, pp 11271137.

Daði Már Kristofersson og Kyrre Rickertsen (2007). Hedonic Price Models for Dynamic Markets. The Oxford Bulletin of Economics and Statistics. 69(3), pp 387-412.

Dawson, R. (2003). Vertical integration in commercial fisheries. Doktorsritgerð frá hagfræðideild Virginia Tech University.

Gudmundsson, E., Ashe, F. og Nielsen, M. (2006). Revenue Distribution through the Seafood Value Chain. Retrieved November 18, 2007, from Fisheries and Aquaculture Department Site: http://www.fao.org/docrep/009/a0564e/a0564e00.htm

Hagfræðistofnun. (2011). Fjárhagslegur aðskilnaður fiskveiða og vinnslu:Kostir og gallar. Reykjavík: Háskóli Íslands

Hagstofa Íslands. (e.d.a.). AFKOMA. Sótt í apríl 2012 af http://hagstofa.is/Hagtolur/Sjavarutvegur-og-landbunadur/Afkoma

Hagstofa Íslands (e.d.b.) Samsetning útflutnings. Sótt í apríl 2012 af http://hagstofa.is/Hagtolur/Sjavarutvegur-og-landbunadur/Utflutningur

Háskólasetur Vestfjarða. (2010). Úttekt á framgangi og áhrifum strandveiðanna sumarið 2009. Ísafjörður: Háskólasetur Vestfjarða

Herrmann, M. (1996). Estimating the induced price increase for Canadian Pacific Halibut with the introduction of the individual vessel quota system. Canadian Journal of Agricualtural Economics, 44:151-64.

Herrmann, M. (2000). Individual vessel quota price-induced effects for Canadian Pacific halibut: Before and after Alaska IFQs. Canadian Journal of Agricultural EconomicsRevue Canadienne D Agroeconomie, 48, pp 195-210.

Homans, F.R. og Wilen, J.E. (2005). Markets and rent dissipation in regulated open access fisheries. Journal of Environmental Economics and Management 49:381-404.

Jónas R Viðarsson, Sveinn Margeirsson og Sigurjón Arason (2010). Smábátar Hámörkun aflaverðmætis. Skýrsla Matís 49-10. Reykjavík: Matís.

Knutsson, Ö. , Klemensson, Ó. og Gestsson, H. (2008). Structural changes in the Icelandic fisheries sector - a value chain analysis. Proceeding of the 14th Annual biennial Conference of International Institutes of Fisheries and Economics and Trade, IIFET.

Knutsson, Ö., Klemensson, Ó. og Gestsson, H. (2010). The Role of Fish Markets in the Icelandic Value Chain of Cod. Proceeding of the 15th Annual biennial Conference of International Institutes of Fisheries and Economics and Trade, IIFET. 
Larkin, S. L. og Sylvia, G. (1999). Intrinsic fish characteristics and intraseason production efficiency: A management-level bioeconomic analysts of a commercial fishery. American Journal of Agricultural Economics, 81, 29-43.

Matulich, S. C., Mittelhammer , R. C. og Reberte, C. (1996). Toward a more complete model of individual transferable fishing quotas: Implications of incorporating the processing sector. Journal of Environmental Economics and Management, 31, 112-128.

McConnell, K. E. og Strand, I. E. (2000). Hedonic prices for fish: Tuna prices in Hawaii. American Journal of Agricultural Economics, 82, pp 133-144.

Norvegian Seafood Counsil. (e.d.). Exportutvalget for fisk. Sótt í apríl 2012 af http://seafood.no/Markedsinformasjon/Statistikk

Seðlabanki Íslands. (e.d.). Gengi Gjaldmiðla. Sótt í apríl 2012 af http://www.sedlabanki.is/default.aspx?pageid=4695b8f3-cd54-4435-8812$5179369 \mathrm{c} 410 \mathrm{a}$

Statistisk Sentralbyrå (e.d). EBITDA. Sótt í apríl 2012 af http://www.ssb.no/fiskeri_havbruk/

Weninger, Q. (1999). Equilibrium prices in a vertically coordinated fishery. Journal of Environmental Economics and Management, 37, pp 290-305.

Pingskjal 609. (1989-1990) Lagasafn. Frumvarp til laga 609, 1989-90. Sótt í apríl 2012 af http://www.althingi.is/altext/112/s/0609.html

Ögmundur H. Knútsson, (2001). Strategic Alliances; The Role of Central Firm in Governing Strategic Alliances Between Small and Medium Size Companies; The Case in the Icelandic Fish Industry. Óutgefin doktorsritgerð. University of Edinburgh, Scotland. 